\title{
Cardiomyocyte dysfunction during the chronic phase of Chagas disease
}

\author{
Danilo Roman-Campos ${ }^{1 /+}$, Policarpo Sales-Júnior ${ }^{2}$, Hugo Leonardo Duarte', Eneas Ricardo Gomes ${ }^{3}$, \\ Silvia Guatimosim ${ }^{3}$, Catherine Ropert ${ }^{2}$, Ricardo Tostes Gazzinelli², Jader Santos Cruz ${ }^{1}$ \\ Laboratório de Membranas Excitáveis e Biologia Cardiovascular, Departamento de Bioquímica e Imunologia \\ ${ }^{3}$ Laboratório de Sinalização Intracelular em Cardiomiócitos, Departamento de Fisiologia e Farmacologia, \\ Instituto de Ciências Biológicas, Universidade Federal de Minas Gerais, Belo Horizonte, MG, Brasil \\ ${ }^{2}$ Laboratório de Imunopatologia, Centro de Pesquisas René Rachou-Fiocruz, Belo Horizonte, MG, Brasil
}

\begin{abstract}
Chagas disease, which is caused by the parasite Trypanosoma cruzi, is an important cause of heart failure. We investigated modifications in the cellular electrophysiological and calcium-handling characteristics of an infected mouse heart during the chronic phase of the disease. The patch-clamp technique was used to record action potentials $(A P s)$ and L-type $\mathrm{Ca}^{2+}$ and transient outward $\mathrm{K}^{+}$currents. $\left[\mathrm{Ca}^{2+}\right]_{i}$ changes were determined using confocal microscopy. Infected ventricular cells showed prolonged APs, reduced transient outward $K^{+}$and L-type Ca ${ }^{2+}$ currents and reduced $\mathrm{Ca}^{2+}$ release from the sarcoplasmic reticulum. Thus, the chronic phase of Chagas disease is characterised by cardiomyocyte dysfunction, which could lead to heart failure.
\end{abstract}

Key words: Chagas disease - calcium current - action potential - potassium current - intracellular calcium - Trypanosoma cruzi

Chagas disease, which is caused by infection with the protozoan parasite Trypanosoma cruzi, is one of the leading causes of heart failure in Latin America (MarinNeto et al. 2007). Currently, 10 million people are infected and 25 million people live in areas where the infectious parasites are present (WHO 2010). However, until now, few studies have provided compelling evidence of cardiomyocyte dysfunction during the establishment of heart failure following infection by T. cruzi (de Carvalho et al. 1992, Pacioretty et al. 1995, Roman-Campos et al. 2009b). Recently, new data have provided supporting evidence of how the left ventricular electrical-mechanical dysfunction observed during the initial stages of chagasic cardiomyopathy occurs (Esper et al. 2012, RomanCampos et al. 2012). However, the cellular mechanisms underlying cardiomyocyte dysfunction during the late stages of Chagas disease remain unknown. Therefore, we sought to determine whether cardiomyocyte function is altered in the late phase of Chagas disease.

Eight-week-old male C57BL/6 mice were intraperitoneally infected with 50 bloodstream trypomastigote forms of a Colombian T. cruzi strain (Federici et al. 1964). The experimental protocols were approved by the local animal use and care committee of the Federal University of Minas Gerais.

Adult left ventricular myocytes were enzymatically isolated using collagenase $(1 \mathrm{mg} / \mathrm{mL})$ with a calcium gradient method as previously described (Roman-Campos et al. 2009b). Myocytes were freshly isolated and

Financial support: FAPEMIG, CNPq, PRONEX

+ Corresponding author:drcbio@gmail.com

Received 2 August 2012

Accepted 22 November 2012 stored in Dulbecco's Modified Eagle's Medium until they were used for experiments (within 4-6 h). Only calcium-tolerant, quiescent, rod-shaped myocytes showing clear cross-striations were used.

The whole-cell patch-clamp method was used in the current and voltage-clamp modes. All experiments were performed at room temperature $\left(23-26^{\circ} \mathrm{C}\right)$. To measure action potentials (APs) and transient outward $\mathrm{K}^{+}\left(\mathrm{I}_{\mathrm{to}}\right)$ and L-type $\mathrm{Ca}^{2+}$ currents $\left(\mathrm{I}_{\mathrm{Ca}, \mathrm{L}}\right.$ ), patch pipettes were filled with the appropriate internal solutions and bathed with external solutions as previously described (Roman-Campos et al. 2009a). APs were elicited at $1 \mathrm{~Hz}$ using short-current square pulses (3-5 ms). $\mathrm{I}_{\text {to }}$ was elicited by $3 \mathrm{~s}$ depolarisation pulses ranging from -40 to $+70 \mathrm{mV}$ from a holding potential of $-80 \mathrm{mV}$ at increments of $10 \mathrm{mV}(15 \mathrm{~s}$ interval). $I_{C a, L}$ was measured at a holding potential of $-80 \mathrm{mV}$, which was increased to $-40 \mathrm{mV}$ for $50 \mathrm{~ms}$ to inactivate $\mathrm{Na}+$ and T-type $\mathrm{Ca}^{2+}$ channels. $\mathrm{I}_{\mathrm{Ca}, \mathrm{L}}$ was then measured at different membrane voltages between -40 and $50 \mathrm{mV}$ ( $300 \mathrm{~ms}$ duration and $10 \mathrm{~s}$ intervals between test pulses).

$\mathrm{Ca}^{2+}$ imaging was performed in Fluo-4 AM (10 $\mu \mathrm{M})$-loaded cardiomyocytes that were stimulated at 1 $\mathrm{Hz}$ using a Zeiss LSM 510 META confocal microscope equipped with an argon laser $(488 \mathrm{~nm})$ and a $63 \mathrm{X}$ oil immersion objective in line-scan mode (Roman-Campos et al. 2010). The intracellular $\mathrm{Ca}^{2+}$ levels were reported as the $\mathrm{F} / \mathrm{F}_{0}$ ratio, where $\mathrm{F}$ is the maximal measured fluorescence and $\mathrm{F}_{0}$ is the background fluorescence. To fit $\mathrm{Ca}^{2+}$ transient decay, we used a mono-exponential function.

All results are expressed as the mean \pm standard error of the mean (SEM). For statistical analysis, we used Student's $t$ test and $\mathrm{n}$ represents the number of different cells. $p<0.05$ was considered statistically significant.

To study the cellular mechanism of cardiomyocyte dysfunction during the chronic phase of Chagas disease, in which T. cruzi is no longer observed in the bloodstream (Roman-Campos et al. 2009b), we first measured the transmembrane APs of cardiomyocytes isolated from 
control and infected mice [200 days post-infection (dpi)]. Chagasic cardiomyopathy caused an increase in the time to AP repolarisation (APR). The lengths of time to $90 \%$ APR were $27.9 \pm 2.2 \mathrm{~ms}(\mathrm{n}=13)$ and $36.2 \pm 2.7 \mathrm{~ms}(\mathrm{n}=$ 13) in control and infected mice, respectively (Fig. 1A, B). The regulation of APR in mouse cardiac myocytes is dependent on $\mathrm{I}_{\text {to }}$ (Roman-Campos et al. 2010). As shown in Fig. 1C, D, at 200 dpi, cardiomyocytes showed a significant reduction in $\mathrm{I}_{\text {to }}$ density. The peak outward $\mathrm{K}^{+}$ current density at $+50 \mathrm{mV}$ was $25.9 \pm 3.0 \mathrm{pA} / \mathrm{pF}(\mathrm{n}=13)$ and $14.3 \pm 0.5 \mathrm{pA} / \mathrm{pF}(\mathrm{n}=4)$ in control and infected cardiac myocytes, respectively. In addition to $\mathrm{I}_{\mathrm{to}}, \mathrm{I}_{\mathrm{Ca}, \mathrm{L}}$ also plays an important role in the control of AP waveform, mainly in the plateau phase. As shown in Fig. 2A, B, $\mathrm{I}_{\mathrm{Ca}, \mathrm{L}}$ was compromised in diseased mice. At $0 \mathrm{mV}$, the $\mathrm{I}_{\mathrm{Ca}, \mathrm{L}}$ was $-7.2 \pm 0.6 \mathrm{pA} / \mathrm{pF}(\mathrm{n}=8)$ and $-5.5 \pm 0.4 \mathrm{pA} / \mathrm{pF}(\mathrm{n}$ $=7$ ) in control and infected cardiac myocytes, respectively. Furthermore, $\mathrm{I}_{\mathrm{Ca}, \mathrm{L}}$ plays a central role in triggering calcium release from the sarcoplasmic reticulum (SR); thus, reduced $\mathrm{I}_{\mathrm{Ca}, \mathrm{L}}$ could impair calcium release from the SR (Roman-Campos et al. 2010). As shown in Fig. 2C, $\mathrm{D}$, cardiomyocytes isolated from infected mice showed a $\sim 17 \%$ reduction in calcium release from the SR compared to control cardiomyocytes. Additionally, calcium reuptake into the SR, which was measured as the calcium transient decay time constant, was slowed by $\sim 39 \%$ in myocytes isolated from infected mice (Fig. 2E).

In the present study, at $200 \mathrm{dpi}$, we showed that chagasic cardiomyopathy led to profound cardiomyocyte dysfunction due to (i) AP prolongation, (ii) reduced tran-
A

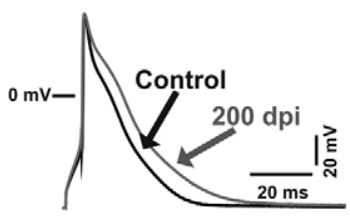

C

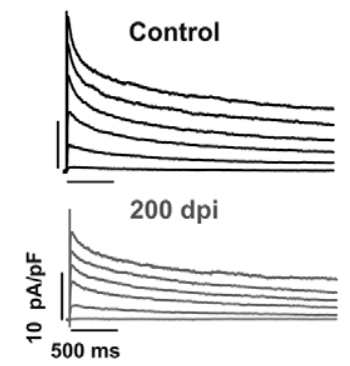

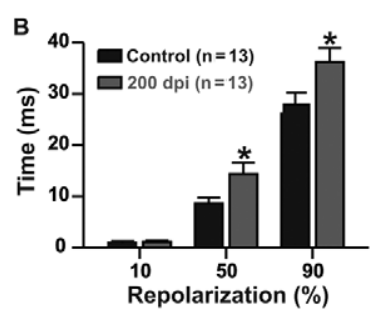

D

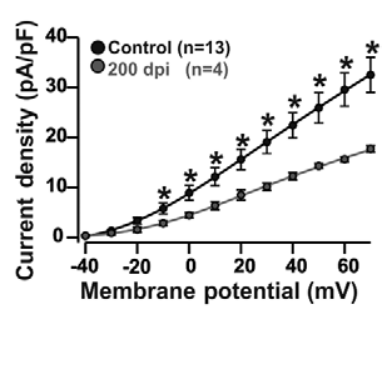

Fig. 1: prolonged action potential (AP) in chagasic cardiomyocyte at 200 days post-infection (dpi). A: representative AP traces from control (black) and chagasic cardiomyocytes (gray); B: AP repolarisation duration at different repolarisation levels; C: reduced transient outward $\mathrm{K}^{+}$current $\left(\mathrm{I}_{\mathrm{to}}\right)$ in Chagas disease; D: voltage-dependence of $\mathrm{I}_{\text {to }}$ plotted as current density $(\mathrm{pA} / \mathrm{pF})$ vs. membrane potential $(\mathrm{mV})$ (control: black circles; chagasic cardiomyocytes: gray circles). Continuous lines were obtained by nonlinear regression analysis. Asterisks mean $\mathrm{p}<0.05$. n: number of cells. sient outward potassium and L-type calcium currents and (iii) reduced calcium release from the SR.

In previous studies, our and other groups have provided evidence showing that Chagas disease causes the disruption of heart and cardiomyocyte function, primarily due to a sustained inflammatory response, leading to nitric oxide and superoxide anion production (de Carvalho et al. 1992, Machado et al. 2000, Wen et al. 2006, Macao et al. 2007, Sales et al. 2008, RomanCampos et al. 2009a, 2012). Additionally, it is accepted that sustained and excessive superoxide production is able to downregulate heart and cardiomyocyte function, mainly through the disruption of excitation-contraction coupling (Prosser et al. 2011) and reduction of Kv4.3 expression (Zhou et al. 2006). Nitric oxide is also able to differentially modulate cardiomyocyte function depending on its concentration (Gonzalez et al. 2008). Thus, it is reasonable to postulate that cardiomyocyte dysfunction during the late phase of Chagas disease is due to the excessive production of both nitric oxide (Roman-Campos et al. 2012) and superoxide anion.
A

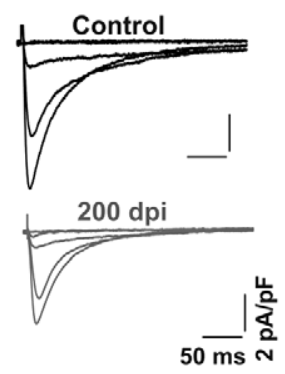

C

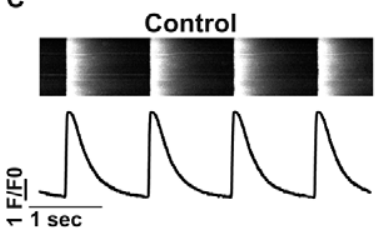

D

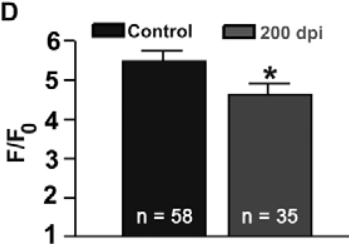

B
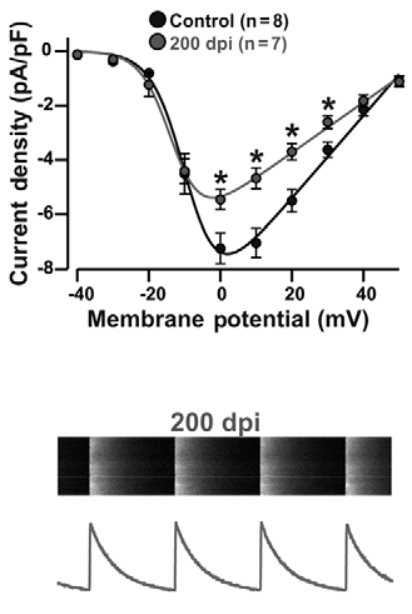

E

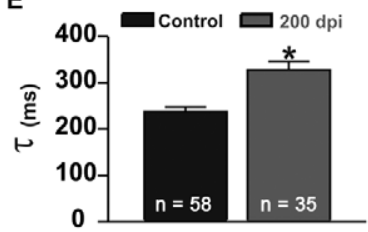

Fig. 2: disrupted excitation-contraction coupling in chagasic cardiomyocytes. A: representative $\mathrm{I}_{\mathrm{C}, \mathrm{L}}$ recordings from control (top) and chagasic cardiomyocytes (bottom); B: voltage-dependence of $\mathrm{I}_{\mathrm{Ca}}$ plotted as current density ( $\mathrm{pA} / \mathrm{pF}$ ) from -40 to $50 \mathrm{mV}$ (control: black circles; chagasic cardiomyocytes: gray circles); C: representative intracellular global $\mathrm{Ca}^{2+}$ transients obtained from electrically stimulated myocytes (top). $\mathrm{Ca}^{2+}$ transient profile (bottom); D: significant reduction in peak $\mathrm{Ca}^{2+}$ transient amplitude observed in freshly isolated adult chagasic ventricular cardiomyocytes compared to the amplitude of control myocytes; E: time-constant of $\mathrm{Ca}^{2+}$ transient decay in chagasic and control cardiomyocytes. Asterisks mean $\mathrm{p}<0.05$. dpi: days post-infection; n: number of cells. 
Additionally, we observed reduced calcium release and slowed calcium reuptake into the SR at $200 \mathrm{dpi}$, both of which are hallmarks of human and mouse models of heart failure (Gwathmey et al. 1987, Lara et al. 2010, Roman-Campos et al. 2010). Thus, our results could explain the reduced heart function observed in the chronic phase of Chagas disease in mice (Jelicks et al. 2002) and may be translated to humans (Marin-Neto et al. 2007). However, additional studies with human cardiac tissue are necessary to confirm this possibility.

\section{REFERENCES}

de Carvalho AC, Tanowitz HB, Wittner M, Dermietzel R, Roy C, Hertzberg EL, Spray DC 1992. Gap junction distribution is altered between cardiac myocytes infected with Trypanosoma cruzi. Circ Res 70: 733-742.

Esper L, Roman-Campos D, Lara A, Brant F, Castro LL, Barroso A, Araujo RR, Vieira LQ, Mukherjee S, Gomes ER, Rocha NN, Ramos IP, Lisanti MP, Campos CF, Arantes RM, Guatimosim S, Weiss LM, Cruz JS, Tanowitz HB, Teixeira MM, Machado FS 2012. Role of SOCS2 in modulating heart damage and function in a murine model of acute Chagas disease. Am J Pathol 181: 130-140.

Federici EE, Abelmann WH, Neva FA 1964. Chronic and progressive myocarditis and myositis in C3h mice infected with Trypanosoma cruzi. Am J Trop Med Hyg 13: 272-280.

Gonzalez DR, Fernandez IC, Ordenes PP, Treuer AV, Eller G, Boric MP 2008. Differential role of S-nitrosylation and the NO-cGMPPKG pathway in cardiac contractility. Nitric Oxide 18: 157-167.

Gwathmey JK, Copelas L, MacKinnon R, Schoen FJ, Feldman MD, Grossman W, Morgan JP 1987. Abnormal intracellular calcium handling in myocardium from patients with end-stage heart failure. Circ Res 61: 70-76.

Jelicks LA, Chandra M, Shtutin V, Petkova SB, Tang B, Christ GJ, Factor SM, Wittner M, Huang H, Douglas SA, Weiss LM, Orleans-Juste PD, Shirani J, Tanowitz HB 2002. Phosphoramidon treatment improves the consequences of chagasic heart disease in mice. Clin Sci (Lond) 103 (Suppl. 48): 267S-271S.

Lara A, Damasceno DD, Pires R, Gros R, Gomes ER, Gavioli M, Lima RF, Guimaraes D, Lima P, Bueno Jr CR, Vasconcelos A, Roman-Campos D, Menezes CA, Sirvente RA, Salemi VM, Mady C, Caron MG, Ferreira AJ, Brum PC, Resende RR, Cruz JS, Gomez MV, Prado VF, de Almeida AP, Prado MA, Guatimosim S 2010. Dysautonomia due to reduced cholinergic neurotransmission causes cardiac remodeling and heart failure. $\mathrm{Mol}$ Cell Biol 30: 1746-1756.
Macao LB, Wilhelm Filho D, Pedrosa RC, Pereira A, Backes P, Torres MA, Frode TS 2007. Antioxidant therapy attenuates oxidative stress in chronic cardiopathy associated with Chagas' disease. Int J Cardiol 123: 43-49.

Machado FS, Martins GA, Aliberti JC, Mestriner FL, Cunha FQ, Silva JS 2000. Trypanosoma cruzi - infected cardiomyocytes produce chemokines and cytokines that trigger potent nitric oxidedependent trypanocidal activity. Circulation 102: 3003-3008.

Marin-Neto JA, Cunha-Neto E, Maciel BC, Simoes MV 2007. Pathogenesis of chronic Chagas heart disease. Circulation 115: 1109-1123.

Pacioretty LM, Barr SC, Han WP, Gilmour Jr RF 1995. Reduction of the transient outward potassium current in a canine model of Chagas disease. Am J Physiol 268: 1258-1264.

Prosser BL, Ward CW, Lederer WJ 2011. X-ROS signaling: rapid mechano-chemo transduction in heart. Science 333: 1440-1445.

Roman-Campos D, Campos AC, Gioda CR, Campos PP, Medeiros MA, Cruz JS 2009a. Cardiac structural changes and electrical remodeling in a thiamine-deficiency model in rats. Life Sci 84: 817-824.

Roman-Campos D, Duarte HL, Gomes ER, Castro CH, Guatimosim S, Natali AJ, Almeida AP, Pesquero JB, Pesquero JL, Cruz JS 2010. Investigation of the cardiomyocyte dysfunction in bradykinin type 2 receptor knockout mice. Life Sci 87: 715-723.

Roman-Campos D, Duarte HL, Sales PA Jr, Natali AJ, Ropert C, Gazzinelli RT, Cruz JS 2009b. Changes in cellular contractility and cytokines profile during Trypanosoma cruzi infection in mice. Basic Res Cardiol 104: 238-246.

Roman-Campos D, Sales-Junior PA, Duarte HL, Gomes ER, Lara A, Rocha NN, Resende RR, Ferreira A, Guatimosim S, Gazzinelli RT, Ropert C, Cruz JS 2012. Novel insights into the development of chagasic cardiomyopathy: role of PI3Kinase/NO axis. Int $J$ Cardiol S0167-5273: 01126-01136.

Sales PA Jr, Golgher D, Oliveira RV, Vieira V, Arantes RM, LannesVieira J, Gazzinelli RT 2008. The regulatory $\mathrm{CD}^{+} \mathrm{CD} 25^{+} \mathrm{T}$ cells have a limited role on pathogenesis of infection with Trypanosoma cruzi. Microbes Infect 10: 680-688.

Wen JJ, Yachelini PC, Sembaj A, Manzur RE, Garg NJ 2006. Increased oxidative stress is correlated with mitochondrial dysfunction in chagasic patients. Free Radic Biol Med 41: 270-276.

WHO - World Health Organization 2010. Chagas disease (American trypanosomiasis) fact sheet (revised in June 2010). Wkly Epidemiol Rec 85: 329-336.

Zhou C, Ziegler C, Birder LA, Stewart AF, Levitan ES 2006. Angiotensin II and stretch activate NADPH oxidase to destabilize cardiac Kv4.3 channel mRNA. Circ Res 98: 1040-1047. 